\title{
Erratum to evaluation of long-term breast shape in inferior versus superomedial pedicle reduction mammoplasty: a comparative study
}

\section{Editorial Office}

Gland Surgery

Correspondence to: Editorial Office, Gland Surgery. Email: editor@glandsurgery.org.

doi: $10.21037 / g s-2020-04$

View this article at: http://dx.doi.org/10.21037/gs-2021-04

Erratum to: Gland Surg 2021;10:1018-28

In issue Vol 10, No 3 (March 2021) published in Gland Surgery, the paper "Evaluation of long-term breast shape in inferior versus superomedial pedicle reduction mammoplasty: a comparative study" by Dr. Sapino et al. (1) was published with an error.

The name of the corresponding author "Giovanni di Summa P" in the citation part "Cite this article as: Sapino G, Haselbach D, Watfa W, Baudoin J, Martineau J, Guillier D, Giovanni di Summa P. Evaluation of long-term breast shape in inferior versus superomedial pedicle reduction mammoplasty: a comparative study. Gland Surg 2021;10(3):1018-1028. doi: 10.21037/ gs-20-440" should be corrected as "di Summa PG". Therefore, the corrected version should be "Cite this article as: Sapino G, Haselbach D, Watfa W, Baudoin J, Martineau J, Guillier D, di Summa PG. Evaluation of long-term breast shape in inferior versus superomedial pedicle reduction mammoplasty: a comparative study. Gland Surg 2021;10(3):1018-1028. doi: 10.21037/ gs-20-440"

Please click here to view the updated version of the article.

Open Access Statement: This is an Open Access article distributed in accordance with the Creative Commons AttributionNonCommercial-NoDerivs 4.0 International License (CC BY-NC-ND 4.0), which permits the non-commercial replication and distribution of the article with the strict proviso that no changes or edits are made and the original work is properly cited (including links to both the formal publication through the relevant DOI and the license). See: https://creativecommons.org/licenses/by-nc$\mathrm{nd} / 4.0 \%$.

\section{References}

1. Sapino G, Haselbach D, Watfa W, et al. Evaluation of long-term breast shape in inferior versus superomedial pedicle reduction mammoplasty: a comparative study. Gland Surg 2021;10:1018-28.

Cite this article as: Editorial Office. Erratum to evaluation of long-term breast shape in inferior versus superomedial pedicle reduction mammoplasty: a comparative study. Gland Surg 2021;10(5):1840. doi: 10.21037/gs-2021-04 